\title{
Nanoparticle-driven DNA damage mimics irradiation-related carcinogenesis pathways
}

\author{
R.M. Mroz*,\#, R.P.F. Schins ${ }^{\Uparrow}$, H. Li ${ }^{\mp}$, L.A. Jimenez*, E.M. Drost*, A. Holownia ${ }^{+}$, \\ W. MacNee* and K. Donaldson*
}

ABSTRACT: The epidemiological association between cancer and exposure to ambient air pollution particles (particles with a $50 \%$ cut-off aerodynamic diameter of $10 \mu \mathrm{m}$ (PM10)) has been related to the ability of $\mathrm{PM}_{10}$ and its constituent nanoparticles (NPs) to cause reactive oxidative species (ROS)-driven DNA damage. However, there are no data on the molecular response to these genotoxic effects.

In order to assess whether PM10, NP and ROS-driven DNA damage induce carcinogenesis pathways, A549 cells were treated with tert-butyl-hyperperoxide (Tbh), urban dust (UD), carbon black (CB), nanoparticulate CB (NPCB), benzo(a)pyrene (BaP) and NPCB coated with BaP for $\leqslant 24 \mathrm{~h}$. Single- and double-strand breakage of DNA was determined by comet assay; cell cycle status was analysed using flow cytometry. Nuclear extracts or acid-extracted histones were used for Western blot analysis of p-ser15-p53 (p53 phosphorylated at ser15), p53 binding protein (53BP) 1, phospho-histone H2A.X (p-H2A.X) and phospho-BRCA1 (p-BRCA1).

UD caused both single- and double-strand DNA breaks, while other tested NPs caused only single-strand DNA breaks. NPs significantly altered cell cycle kinetics. Tbh enhanced $p-H 2 A . X$ after 1 and $6 \mathrm{~h}$ (2.1- and 2.2-fold, respectively). NP increased 53BP1 expression at $1 \mathrm{~h}$ (2.4-8.7fold) and p-BRCA1 at 1-6 h. N-acetylcysteine blocked NP-driven p-ser15-p53 response.

In conclusion, nanoparticles and reactive oxidative species induce DNA damage, activating p53 and proteins related to DNA repair, mimicking irradiation-related carcinogenesis pathways.

KEYWORDS: DNA damage, H2A.X histone, nanoparticles, particles with a $50 \%$ cut-off aerodynamic diameter of $10 \mu \mathrm{m}$, reactive oxidative species

( ncreased exposures to particles with a $50 \%$ cut-off aerodynamic diameter of $10 \mu \mathrm{m}$ (PM10) is associated with an increased risk of cardiovascular and respiratory deaths and hospital admissions, as well as lung cancer [1,2]. Direct evidence of DNA damage caused by PM10 has also been confirmed [3]. Attention has focused on the PM10 in cities because that is where most deaths occur, where pollution is routinely monitored and hence the associations are best seen. Typical urban PM10 is comprised of $\leqslant 50 \%$ by mass of combustion-derived nanoparticles (CDNPs; particles $<100 \mathrm{~nm}$ ), which are carbon-centred particles, typically from automobile engine exhausts, with associated compounds including transition metals, ammonium salts of nitrogen, sulphur and chlorine plus geological dust and organic matter [4]. Many toxicological studies over the last decade have confirmed that CDNPs readily generate oxidative stress through reactive oxidative species (ROS) and inflammation and nanoparticles (NPs) are seen as the most harmful components of the PM10 mix [5-7].
Several investigators have shown that oxidative stress may play a major role in particle-induced DNA damage, which can be prevented by antioxidants and scavengers of ROS [8]. However, detailed molecular mechanisms involved in the hallmark cellular responses to genotoxic effects are currently not known, in contrast with other DNA damaging agents, such as ionising radiation (IR).

Oxidative stress is now considered to have an important role in regulating cellular signalling, leading to inflammatory, proliferative and genotoxic effects [9-12]. In the case of the latter, a large variety of DNA lesions, including single- and double-strand breaks, and base and sugar damage [13, 14] can all be caused by ROS. Depending on type and severity, acute DNA damage is known to trigger cell cycle arrest, enabling increased DNA repair time, or resulting in cell death [15]. Insufficient or erroneous DNA repair may, in the long-term, result in the accumulation of mutations that are well known
AFFILIATIONS

*ELEGI/Colt Laboratories, University of Edinburgh, Edinburgh, Scotland, UK.

\#Pneumology Dept, and

+Dept of Clinical Pharmacology,

Medical University of Bialystok,

Bialystok, Poland.

"Institut für umweltmedizinische

Forschung, Heinrich-Heine-

University, Düsseldorf, Germany.

CORRESPONDENCE

R.M. Mroz

Pneumology Dep

Medical University of Bialystok

UI. Zurawia 14

Bialystok

Poland

Fax: 48857324149

E-mail: robmroz@wp.pl

Received:

January 182007

Accepted after revision:

November 132007

\section{SUPPORT STATEMENT}

This project was funded by the European Respiratory Society, Fellowship No. LTRF2003-014, awarded to R.M. Mroz, and, in part, by the German Research Council (DFG-SFB503), which was awarded to R.P.F. Schins and H. Li.

STATEMENT OF INTEREST None declared 
to contribute to oncogenesis [16]. Double-strand DNA breaks (DSBs) induced by X-rays, chemicals or during replication of single-strand breaks (SSBs), and presumably during repair of interstrand crosslinks, are the most harmful due to their dramatic impact on the recombination machinery [17-20].

The most widely accepted and extensively used model of DNA damage-induced cell signalling and DNA repair is IR. In this model, signal transduction pathways and participating proteins can be formally divided into sensors, transducers and effectors. Poly (adenosine disphosphate (ADP)-ribose) polymerase, DNA-dependent protein kinase, BRCA1, topoisomerase II binding protein 1, p53 binding protein (53BP) 1, mediator of DNA damage check-point protein (MDC) 1 and H2A.X histone variant are the most likely candidates for sensors. Transducers, such as ataxia/teleangiectasia mutated (ATM) and ataxia/teleangiectasia receptor (ATR) kinases are located immediately downstream from the sensors, playing an important role in the DNA damage check-point by controlling the initial phosphorylation of several key proteins of the overall response, such as p53, Mdm2, BRCA1, Chk2, MDC1, NBS1 and H2A.X, since distinctions between groups of proteins are not absolutely clear and they may be found at different levels downstream of the pathway [21, 22]. The present authors have drawn on these mechanisms to derive the hypothesis that exposure to PM10, and specifically the NP component, may result in activation of similar DNA damage response pathways, providing biologically plausible mechanisms for the epidemiological association between PM10 exposure and cancer incidence [1, 2]. The present study has examined these end-points in pulmonary epithelial cells treated with urban dust (UD) and various NPs, to determine the expression of DNA damage-inducible genes. Since the IRinduced DNA damage response is highly complex, the key aim of the present study was to first find some clues for the potential of particles to induce DNA response signals using selected parameters.

\section{MATERIALS AND METHODS Reagents}

All chemicals and reagents used in the present study were obtained from Sigma Chemical (Poole, UK), unless otherwise stated. Cell culture media and reagents were obtained from GIBCO-BRL (Paisley, UK). Tert-butyl-hyperperoxide (Tbh) was prepared in a stock solution of $2 \mathrm{mM}$ in PBS and treatments were carried out at a concentration of $50-75 \mu \mathrm{M}$. The thiol antioxidant $N$-acetyl-L-cysteine (NAC) was stored at $20^{\circ} \mathrm{C}$ in PBS at a concentration of $0.5 \mathrm{M}$ and used at a final concentration of $5 \mathrm{mM}$. NAC was added as a pre-treatment to cells $6 \mathrm{~h}$ before the addition of NPs.

\section{Cell culture}

A549 type II alveolar-like cells derived from human adenocarcinoma expressing wildtype (WT) p53 (ECACC, Porton Down, UK) were cultured in Dulbecco's modified Eagle's medium (DMEM) supplemented with 10\% (weight (w)/ volume (v)) heat-inactivated foetal calf serum, L-glutamine $(2 \mathrm{mM})$ and penicillin-streptomycin solution in $5 \% \mathrm{CO}_{2}$ at $37^{\circ} \mathrm{C}$. Cells were quiesced overnight in serum-free media and subsequently treated under serum-free conditions. All experiments were carried out with A549 cells between passages 6 and 10 .

\section{Particles}

The model particles and chemicals that were used in the present study are listed in table 1 . The rationale for their selection is summarised in the table and was based on the physicochemical properties and/or constituents of particles that are currently considered to be the main driving forces for the induction of oxidative stress, i.e. the particle surface, transition metals or organic constituents such as polycyclic aromatic hydrocarbons [8]. Coarse carbon black (CB: Huber 990; H. Haeffner and Co Ltd, Chepstow, UK) had a primary diameter of $260 \mathrm{~nm}$ and nanoparticulate CB (NPCB: Printex 90; Degussa, Frankfurt, Germany) had a primary diameter of

TABLE 1 Rationale for model particles and chemicals

\begin{tabular}{|c|c|c|}
\hline Particle/chemical & Rationale & [Ref.] \\
\hline Carbon black & $\begin{array}{l}\text { Larger than nanoparticulate carbon black ( } 260 \text { versus } 14 \mathrm{~nm} \text { ) and shown in } \\
\text { various studies not to elicit oxidative stress, hence demonstrating the ability } \\
\text { of surface area to elicit oxidative stress }\end{array}$ & [8] \\
\hline Tert-butyl-hyperperoxide & Pure oxidative stressor, nonparticulate & \\
\hline Urban dust & $\begin{array}{l}\text { Standard reference air pollution particles } \\
\text { Previously shown to induce oxidative DNA damage in human lung epithelial } \\
\text { cells }\end{array}$ & [23-25] \\
\hline Nanoparticulate carbon black & $\begin{array}{l}\text { Model of the carbonaceous nanoparticles in urban dust } \\
\text { The specific sample has been shown to elicit oxidative stress in various } \\
\text { biological cell systems }\end{array}$ & [8] \\
\hline $\begin{array}{l}\text { Nanoparticulate carbon black and } \\
\text { benzo(a)pyrene }\end{array}$ & $\begin{array}{l}\text { Model of nanoparticles with organic component } \\
\text { Has been used along with noncoated nanoparticulate carbon black and } \\
\text { benzo(a)pyrene in lung carcinogenicity studies in rats }\end{array}$ & [23-25] \\
\hline
\end{tabular}



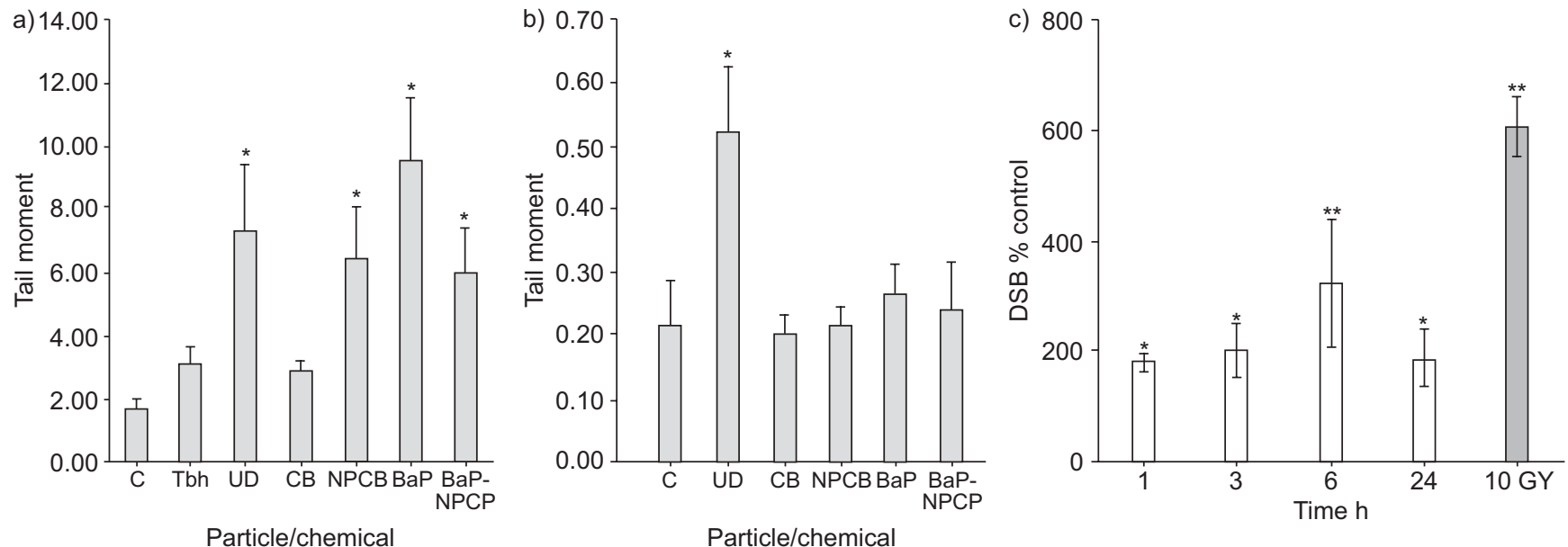

FIGURE 1. DNA single and double strand breakage. a) Alkaline comet assay showing DNA single-strand breaks measured by tail moment after $3 \mathrm{~h}$ treatment of A549 cells with particulate matter. b) Neutral comet assay showing DNA double-strand breaks measured by tail moment after 3 hours treatment of A549 cells with particulate matter. c) Urban dust impact on A549 cells. Time curve for DNA double-strand breaks by urban dust at $100 \mu \mathrm{g} \cdot \mathrm{mL}^{-1}$. C: control; Tbh: tert-butyl-hyperperoxide; UD: urban dust; CB: carbon black; NPCB: nanopartivulate carbon black; BaP: benzo(a)pyrene; BaP-NPCB: nanoparticulate carbon black and benzo(a)pyrene. 피: 10Gy radiation of A549 cells were used as positive internal control throughout all further experiments. *: $p<0.05$ compared with untreated control; **: $p<0.01$ compared with untreated control.

$14 \mathrm{~nm}$. NPCB coated with benzo(a)pyrene (BaP-NPCB) was prepared as follows: NPCB particles were cleaned by Soxhlet extraction with toluene for $8 \mathrm{~h}$. A total of $2 \mathrm{~g}$ of the extracted particles were suspended in $120 \mathrm{~mL} N$-hexane containing $60 \mathrm{mg} \mathrm{BaP}$ for $10 \mathrm{~min}$ and then filtered under vacuum. Following filtration, the BaP-coated particles were washed once with $10 \mathrm{~mL}$ pentane and filtered again under a vacuum, until dry. The resulting BaP content of the coated particles was $26 \mathrm{mg} \mathrm{BaP} \cdot \mathrm{g}^{-1}$ Printex 90, as measured by high performance liquid chromatography using a Grom column and fluorescence detection. Standard Reference Material ${ }_{\circledast}$ 1649a, urban dust (UD) was purchased from the National Institute of Standards and Technology (Gaithersburg, US; [23-25]). For experiments, particles were suspended in foetal bovine serum-free DMEM at concentration of $100 \mu \mathrm{g} \cdot \mathrm{mL}^{-1}\left(25 \mu \mathrm{g} \cdot \mathrm{cm}^{-2}\right)$ and sonicated (Grant Ultrasonic bath XB6; Grant Instruments, Cambridge, England) for $20 \mathrm{~min}$ prior to use.

\section{Cell treatments}

For cell treatments, cells were plated at a density of $0.15 \times 10^{6}$ cells $^{*}$ well $^{-1}$ in petri dishes and grown overnight to $80 \%$ confluency. The medium was then replaced with serumfree medium for a further $24 \mathrm{~h}$. Treatments were also added for specific times in serum-free medium. For all NP treatments, cells were exposed to $100 \mu \mathrm{g} \cdot \mathrm{mL}^{-1}\left(25 \mu \mathrm{g} \cdot \mathrm{cm}^{-2}\right)$ particles in culture medium unless otherwise stated. Cells were treated with 50-75 $\mu \mathrm{M}$ Tbh, $10 \mu \mathrm{M} \mathrm{BaP}, 100 \mu \mathrm{g} \cdot \mathrm{mL}^{-1} \mathrm{UD}, 100 \mu \mathrm{g} \cdot \mathrm{mL}^{-1}$ $\mathrm{CB}, 100 \mu \mathrm{g} \cdot \mathrm{mL}^{-1} \mathrm{NPCB}, 100 \mu \mathrm{g} \cdot \mathrm{mL}^{-1} \mathrm{BaP}-\mathrm{NPCB}$ and $5 \mathrm{mM}$ NAC for $0.5-24 \mathrm{~h}$. The BaP concentration used was equivalent to that of the NP-bound BaP (i.e. BaP-NPCB; $2.6 \mu \mathrm{g} \cdot \mathrm{mL}^{-1}$ ).

\section{Cytotoxicity}

Cytotoxicity was assessed by lactate dehydrogenase (LDH) release. Cells were grown to confluency in 96-well flatbottomed culture plates in media containing $2 \%$ FBS $(\mathrm{v} / \mathrm{v})$ and exposed to a range of NP concentrations $\left(1-100 \mu \mathrm{g} \cdot \mathrm{mL}^{-1}\right)$ for the various time intervals. $\mathrm{LDH}$ release was measured according to manufacturer's instructions (Roche Molecular Biochemicals, Mannheim, Germany) using pyurvic acid as a substrate.

\section{DNA strand breakage analysis}

DNA strand breakage analysis was performed using the alkaline and neutral modifications of the comet assay, which detect DNA SSB plus alkali-labile sites and DSB, respectively $[26,27]$. Cells were seeded into 24-well culture dishes $\left(1.2 \times 10^{5}\right.$ cells $\cdot$ dish $\left.^{-1}\right)$ and grown for a further $48 \mathrm{~h}$, after which the medium was replaced by serum-free medium for $24 \mathrm{~h}$ prior to NP treatment. Following treatment of the cells with $\mathrm{NP}$, the monolayers were rinsed twice with PBS, detached with trypsin-EDTA and immediately suspended in complete culture medium. Cells were then processed for the alkaline comet assay, as described in detail previously [27]. For the neutral assay the same method was used with a lysis buffer set at pH 7.5. DNA damage was analysed on an Olympus BX60 fluorescence microscope at $200 \times$ magnification using software-assisted determination of tail moments (Comet assay II; Perceptive Instruments Ltd, Suffolk, UK).

\section{Cell cycle}

Determination of cell viability and proliferation was estimated by flow cytometric quantification of the cellular DNA, using propidium iodide (PI) staining in permeabilised cells [8]. Briefly, cellular DNA degradation and cell cycle analysis were performed on cells stained for $30 \mathrm{~min}$ with PI $\left(50 \mathrm{mg} \cdot \mathrm{mL}^{-1}\right)$ in tris buffer $(100 \mathrm{mM}, \mathrm{pH} 7.5)$ containing potassium cyanide $(0.1 \%(\mathrm{w} / \mathrm{v}))$, Nonidet-P40 $(0.01 \% \quad(\mathrm{w} / \mathrm{v}))$, RNase III-A $\left(40 \mathrm{mg} \cdot \mathrm{mL}^{-1}, 4 \mathrm{KU} \cdot \mathrm{mL}^{-1}\right)$ and $\mathrm{NaN}_{3}(0.1 \%(\mathrm{w} / \mathrm{v}))$. The analysis was performed on an aligned Coulter Epics Profile flow cytometer (Coulter, Hialeah, FL, USA) equipped with an argon laser operating at $488 \mathrm{~nm}$. PI fluorescence was measured in $\geqslant 5,000$ cells with appropriate bandpass filters. DNA histograms were further analysed by DNA quantification software (MultiCycle; Phoenix Flow Systems Inc., San Diego, CA, USA). 


\begin{tabular}{|c|c|c|c|c|c|}
\hline Control & & $2 \pm 0.57$ & $58 \pm 5$ & $29 \pm 6$ & $13 \pm 5$ \\
\hline Carbon black & 3 & $3 \pm 0.78$ & $59 \pm 6$ & $28 \pm 4$ & $13 \pm 6$ \\
\hline \multirow[t]{3}{*}{ Tert-butyl-hyperperoxide } & 3 & $4 \pm 0.56$ & $55 \pm 8$ & $31 \pm 5$ & $14 \pm 4$ \\
\hline & 6 & $6 \pm 0.81^{*}$ & $49 \pm 7^{\star}$ & $36 \pm 6$ & $15 \pm 4$ \\
\hline & 24 & $18 \pm 4.00^{\star \star}$ & $48 \pm 7^{\star}$ & $39 \pm 7^{*}$ & $13 \pm 4$ \\
\hline \multirow[t]{2}{*}{ Urban dust } & 3 & $4 \pm 0.45$ & $64 \pm 7$ & $21 \pm 3$ & $15 \pm 3$ \\
\hline & 6 & $9 \pm 0.38^{* *}$ & $68 \pm 5^{\star}$ & $19 \pm 9$ & $13 \pm 4$ \\
\hline \multirow{3}{*}{$\begin{array}{l}\text { Nanoparticulate carbon black } \\
\text { and benzo(a)pyrene }\end{array}$} & 3 & $3 \pm 0.94$ & $59 \pm 7$ & $30 \pm 5$ & $11 \pm 4$ \\
\hline & 6 & $4 \pm 0.29$ & $61 \pm 9$ & $29 \pm 6$ & $13 \pm 6$ \\
\hline & 24 & $4 \pm 0.57$ & $59 \pm 10$ & $27 \pm 8$ & $17 \pm 6$ \\
\hline \multirow[t]{3}{*}{ Benzo(a)pyrene } & 3 & $2 \pm 0.72$ & $57 \pm 9$ & $24 \pm 7$ & $19 \pm 5$ \\
\hline & 6 & $3 \pm 0.61$ & $55 \pm 9$ & $25 \pm 8$ & $20 \pm 7$ \\
\hline & 24 & $5 \pm 0.90^{*}$ & $53 \pm 11$ & $25 \pm 6$ & $22 \pm 5^{\star}$ \\
\hline
\end{tabular}

Data are presented as mean \pm SEM, unless otherwise stated. ${ }^{*}$ : when early $G_{0} / G_{1}$ cell are excluded. *: $p<0.05$ versus untreated control; ${ }^{* *}: p<0.01$ versus untreated control.

Cells were quantified by their relative distribution in the damaged-hypodiploid phase ("early" $\mathrm{G}_{0} / \mathrm{G}_{1}$ zone of the DNA fluorescence histograms), diploid phase $\left(\mathrm{G}_{0} / \mathrm{G}_{1}\right.$ zone, preDNA synthesis/resting), S-phase (DNA synthesis) and $\mathrm{G}_{2} / \mathrm{M}$ phase (post-DNA synthesis/mitosis).

\section{Cells specimen processing and nuclei extraction}

Samples for protein analysis were prepared at various times from confluent A549 cell. Cells were washed three times in icecold PBS, scraped in PBS, pelleted for $15 \mathrm{~s}$ at $14,000 \times g$ and resuspended in $400 \mu \mathrm{L}$ of lysis buffer (10 mM hydroxyethyl piperazine ethane sulphonic acid (HEPES), $50 \mathrm{mM} \mathrm{KCl}, 2 \mathrm{mM}$ $\mathrm{MgCl}_{2}, 1 \mathrm{mM}$ dithiothreitol (DTT), $0.1 \mathrm{mM}$ EDTA, $0.4 \mathrm{mM}$ phenylmethylsulphonyl fluoride (PMSF), $0.2 \mathrm{mM} \mathrm{NaF}$, $0.2 \mathrm{mM}$ sodium orthovanadate, $1 \mu \mathrm{g} \cdot \mathrm{ml}^{-1}$ leupeptin; $\mathrm{pH} 7.8$ ) and incubated on ice for $15 \mathrm{~min}$. Following the addition of $10 \%$ Nonidet-P40, cells were centrifuged at $14,000 \times g$ for $30 \mathrm{~s}$ and the supernatant containing cytoplasmic fraction was aspirated and retained. Pelleted nuclei were resuspended in $50 \mu \mathrm{L}$ of extracting buffer (50 mM HEPES, $50 \mathrm{mM} \mathrm{KCl}, 300 \mathrm{mM} \mathrm{NaCl}$, $0.1 \mathrm{mM}$ EDTA, $1 \mathrm{mM}$ DTT $10 \%(\mathrm{v} / \mathrm{v})$ sterile glycerol, $0.2 \mathrm{mM}$ $\mathrm{NaF}, 0.2 \mathrm{mM}$ sodium orthovanadate, $0.66 \mathrm{mM}$ PMSF; $\mathrm{pH} 7.8$ ), mixed for $20 \mathrm{~min}$ on a rotating platform, centrifuged for $5 \mathrm{~min}$ at $14,000 \times g$. The supernatant containing nuclear proteins was decanted and saved for further Western blot analysis. A $5 \mu \mathrm{L}$ aliquot of each sample was stored at $-80^{\circ} \mathrm{C}$ for protein determination by Bicinchoninic Acid Kit for Protein Determination (Sigma-Aldrich, Irvine, Scotland).

\section{Histone acid extraction}

The nuclear pellet was further resuspended in $150 \mu \mathrm{L}$ of distilled $\mathrm{H}_{2} \mathrm{O}$, and $2.6 \mu \mathrm{L}$ of $11.6 \mathrm{M} \mathrm{HCl}$ (final concentration $0.2 \mathrm{M}$ ) and $1.5 \mu \mathrm{L}$ of $18 \mathrm{M} \mathrm{H}_{2} \mathrm{SO}_{4}$ (final concentration $0.36 \mathrm{M}$ ) was added. Eppendorf tubes were placed in a falcon tube and incubated overnight at $4^{\circ} \mathrm{C}$ on a rotating shaker. Samples were then centrifuged at $13,000 \times g$ at $4^{\circ} \mathrm{C}$ for $10 \mathrm{~min}, 1.1 \mathrm{~mL}$ of icecold acetone was added to the protein supernatant containing acid soluble protein and samples were kept overnight in the freezer $\left(-80^{\circ} \mathrm{C}\right)$ to precipitate. The samples were then centrifuged at $13,000 \times g$ at $4{ }^{\circ} \mathrm{C}$ for $10 \mathrm{~min}$, the supernatant was removed and $1 \mathrm{~mL}$ of ice-cold acetone was added to the pellets, mixed and frozen again for $1 \mathrm{~h}$. After centrifugation at $13,000 \times g$ at $4^{\circ} \mathrm{C}$ for $10 \mathrm{~min}$, the supernatant was decanted, the pellet air-dried, resuspended in $50 \mu \mathrm{L}$ of $\mathrm{dH}_{2} \mathrm{O}$ and finally, the protein was measured using Bicinchoninic Acid Kit for Protein Determination (Sigma-Aldrich).

\section{Protein assay}

BioRad stock reagent was diluted 1:5 with distilled water and $200 \mu \mathrm{L}$ of this diluted reagent was added to a 96-well plate, using triplicate groups per test and sample. A $5 \mu \mathrm{L}$ aliquot of each sample was then added to the appropriate well, mixed and incubated at room temperature for $15 \mathrm{~min}$ before being read on a plate reader at $450 \mathrm{~nm}$. Standards of bovine serum albumin solutions were used, ranging $0.025-2 \mathrm{mg} \cdot \mathrm{mL}^{-1}$.

Analysis of phosphorylation status of p53, 53BP1, H2A.X and BRCA1 expression was performed using sequential 

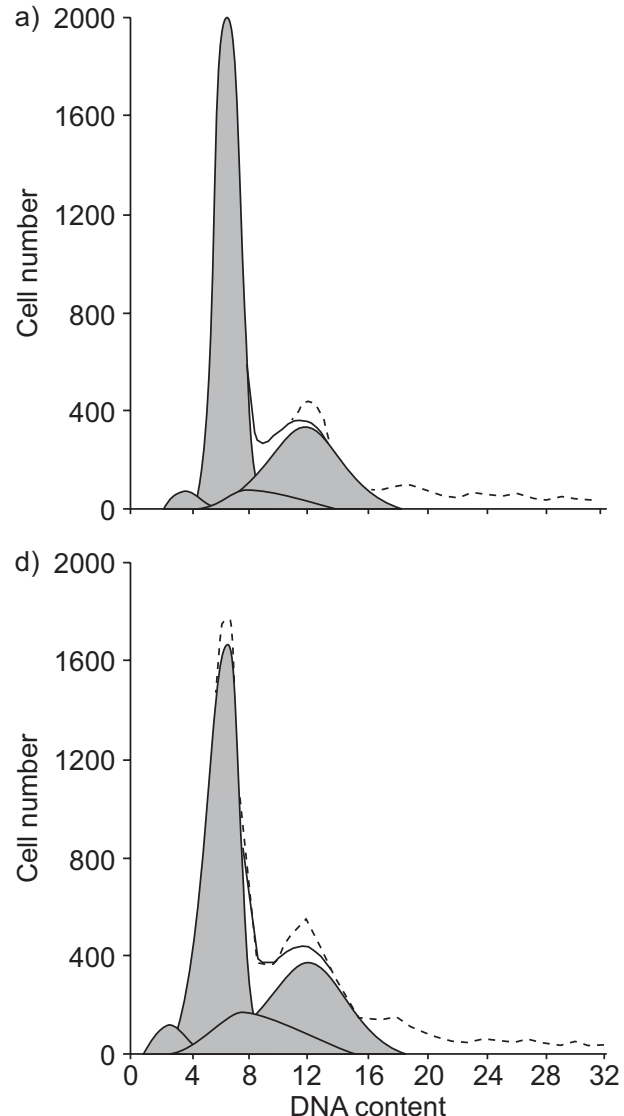

b)

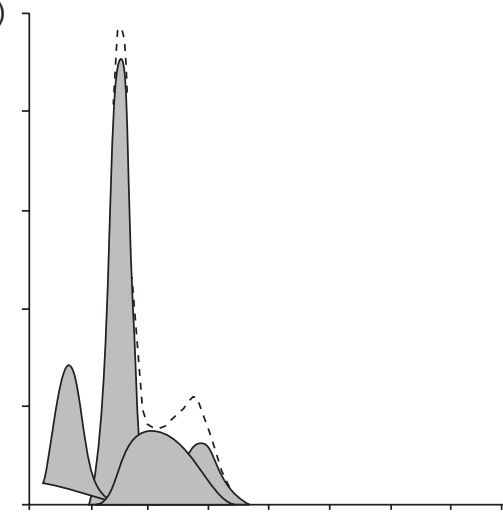

e)

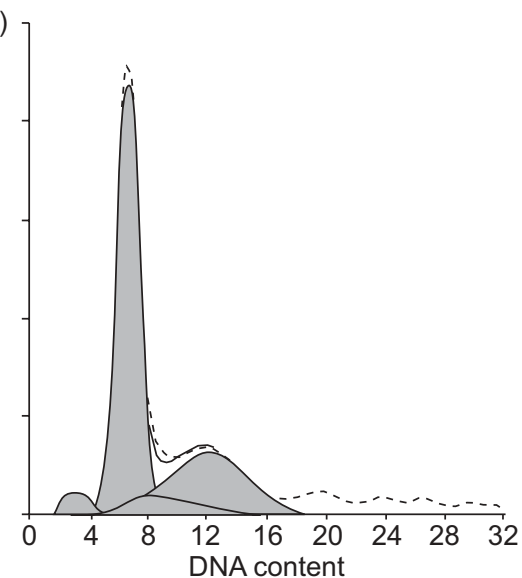

c)

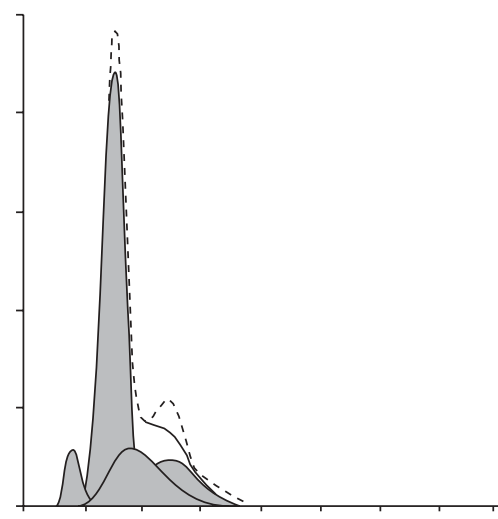

f)

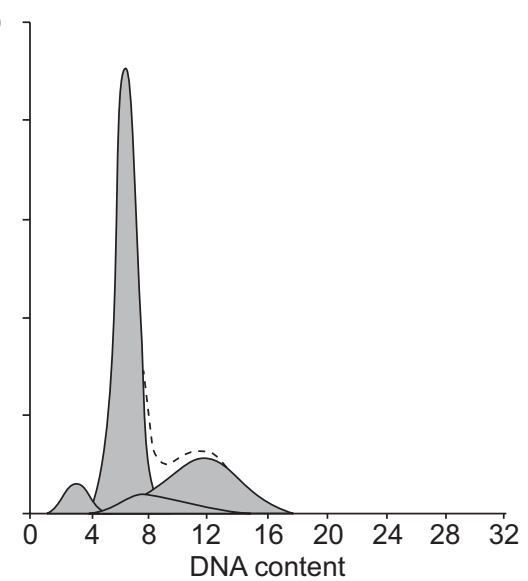

FIGURE 2. Ambient particles and oxidative stress alter cell cycle kinetics. Typical histograms (transformed by DNA analysis software to quantify cell cycle-specific fractions) of propidium iodide fluorescence from: a) control A549 cells; b) cells treated for $24 \mathrm{~h}$ with tert-butyl-hyperperoxide; c) cells treated for $24 \mathrm{~h}$ with urban dust; d) cells exposed to nanoparticulate carbon black for $24 \mathrm{~h}$; e) cells treated with benzo(a)pyrene; and f) cells treated with nanoparticulate carbon black and benzo(a)pyrene.

immunoprecipitations followed by sodium dodecyl sulphate polyacrylamide gel electrophoresis (SDS-PAGE) and/or Western blotting. Equalised amounts of protein lysate (of nuclear extract or histone extract) were boiled at $90^{\circ} \mathrm{C}$ for $5 \mathrm{~min}$ and then analysed by 5-20\% SDS-PAGE. Proteins were transferred to a nitrocellulose membrane and incubated in blocking buffer (3-5\% nonfat dry milk in PBS or tris-buffered saline) for $2 \mathrm{~h}$ before incubation overnight with primary antibody at $4{ }^{\circ} \mathrm{C}$. Subsequently, the blots were probed with peroxidise-conjugated secondary antibody for $0.5-2 \mathrm{~h}$ and the proteins were detected by ECL plus (Pierce, Rockford, IL, USA).

\section{Statistical analysis}

Data were expressed as mean \pm SEM and were analysed using ANOVA with the Tukey multiple comparison test.

\section{RESULTS}

\section{DNA damage in A549 cells}

DNA strand breakage was determined by comet assay (fig. 1). NP exposure caused a significant increase in DNA singlestrand breaks and alkali-labile sites in A549 cells after $3 \mathrm{~h}$ exposure (fig. 1a). Double-strand breaks, detected by neutral comet assay, occurred only in cells treated with UD (fig. 1b). The time-course of UD exposure showed a peak in DNA breakage at 6 h (300\% of control; fig. 1c). In comparison, 10-Gy radiation of the cells, which was used as a positive control, caused an immediate damage reaching $600 \%$ of control. Cells remained viable by trypan blue dye exclusion and no differences between exposure groups were observed (data not shown).

\section{Cell cycle status}

Cell cycle status was assessed at 3, 6 and $24 \mathrm{~h}$ by flow cytometry (table 2, fig. 2). All experiments were expressed as mean values of cell cycle distribution and compared with corresponding controls. Ambient particles and oxidative stress altered cell cycle kinetics. Specifically, UD caused significant $\mathrm{G}_{0} / \mathrm{G}_{1}$ arrest of exposed cells, whereas $\mathrm{NPCB}$ and $\mathrm{BaP}$ exposure resulted in significant $G_{2}$ block of A549 cells. Tbhexposed cells accumulated significantly more cells at early $G_{0} /$ $\mathrm{G}_{1}$ phase.

\section{p53 phosphorylation at ser15}

Immunoprecipitation followed by immunoblot was used to detect p53 protein phosphorylated at ser15 in cells exposed to particles and $\mathrm{BaP}$ for different times ranging $0.5-24 \mathrm{~h}$ (figs $3 \mathrm{a}$ and $3 \mathrm{c}$ ). The results show that p53 phosphorylation on ser15 occurred in response to all tested NPs but not with $\mathrm{CB}$ or $\mathrm{BaP}$ NPCB. The highest response was achieved after 1-h exposure to Tbh (9.6-fold increase), NPCB (7.3-fold increase), UD (5.2fold increase) and $\mathrm{BaP}$ (3.3-fold increase; fig. 3c). Pre-treatment 


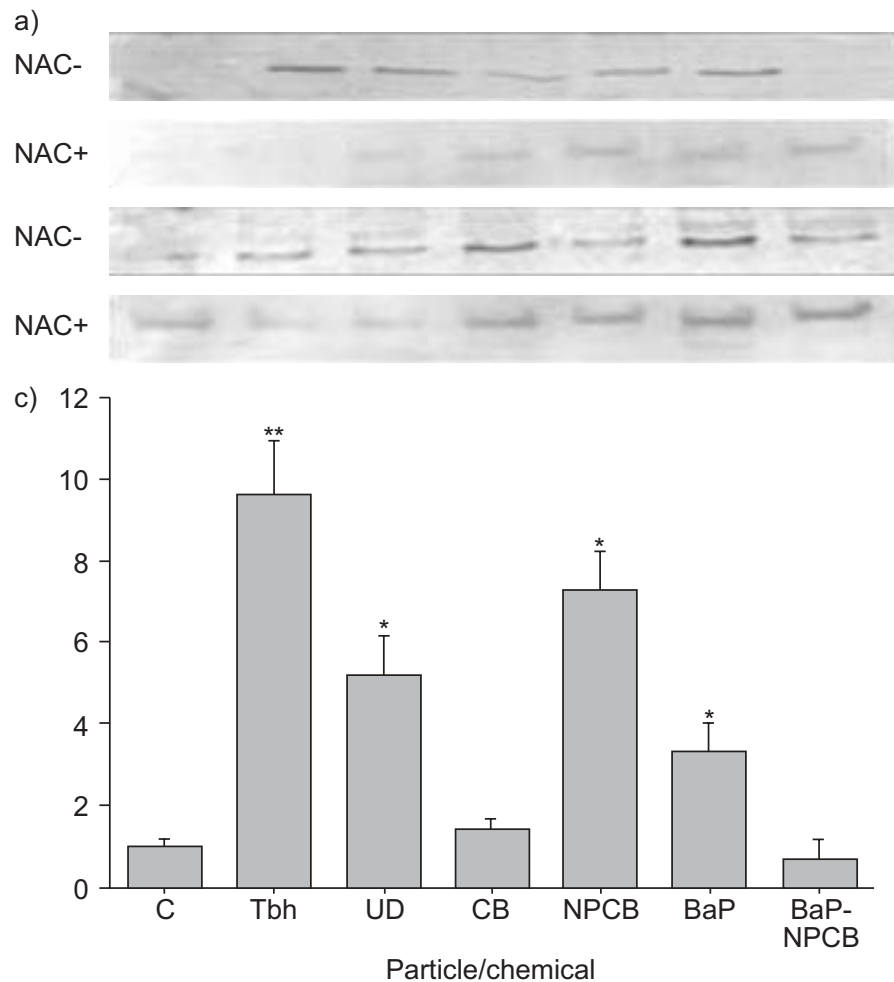

b) Total p53

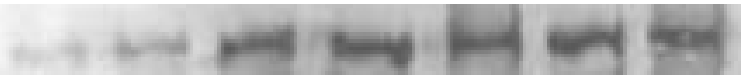

d)

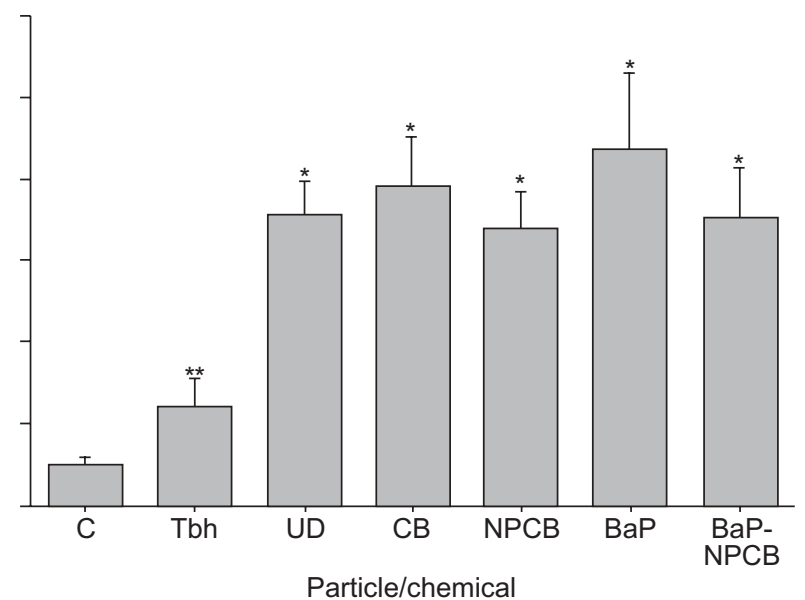

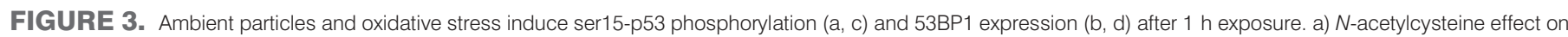

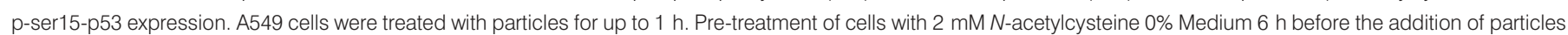

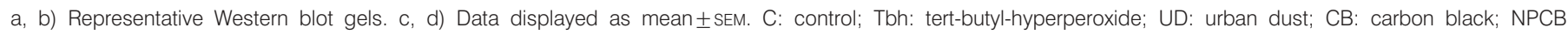

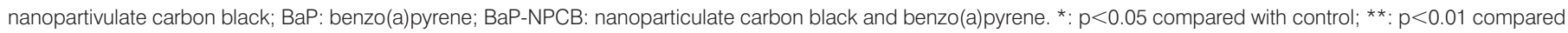
with control.

of cells with NAC for 6 h blocked ser15 p53 phosphorylation in treated cells (fig. 3a), indicating an oxidative stress-driven mechanism.

\section{BP1 expression}

53BP1 expression in A549 cells increased significantly after $1 \mathrm{~h}$ exposure (figs $3 b$ and 3d): Tbh, 2.4-fold; UD, 7.1-fold; CB, 7.8fold; NPCB, 6.8-fold; BaP, 8.7-fold; and BaP-NPCB, 7.0-fold, respectively. Pre-treatment of cells with NAC did not block 53BP1 expression (data not shown).

\section{H2A.X histone phosphorylated on serine 139- $\gamma$ H2A.X}

Expression of $\gamma \mathrm{H} 2 \mathrm{~A} . \mathrm{X}$ was detected in response to $75 \mu \mathrm{M}$ Tbh after 1 and $6 \mathrm{~h}$ (2.1- and 2.3-fold, respectively) and BaP-NPCB after $1 \mathrm{~h}$ (1.2-fold; figs $4 \mathrm{a}$ and $4 \mathrm{~b})$. Further A549 cells were exposed to $50 \mu \mathrm{M}$ Tbh and PM10 for $24 \mathrm{~h}$. Expression of $\gamma \mathrm{H} 2 \mathrm{~A} . \mathrm{X}$ was detected in response to UD and NPCB (1.46- and 1.27-fold, respectively; figs $4 \mathrm{c}$ and $4 \mathrm{~d}$ ). Pre-treatment of cells with $2 \mathrm{mM} \mathrm{N}$-acetylcysteine $0 \%$ medium $6 \mathrm{~h}$ before the addition of particles did not show conclusive data (data not shown).

\section{BRCA1 phosphorylation and 53BP1 expression}

BRCA1 phosphorylation in A549 cells, increased after $1 \mathrm{~h}$ exposure of Tbh, UD and CB at $1 \mathrm{~h}$ and after $6 \mathrm{~h}$ exposure of all tested agents, including CB (fig. 5). Pre-treatment of cells with NAC $(6 \mathrm{~h})$ blocked BRCA1 phosphorylation in treated cells (figs $5 \mathrm{a}$ and $5 \mathrm{c}$ ). However, the NAC effect delayed BRCA1 phosphorylation expression; while in the nonNAC-treated cells the protein expression waned at 6 and $24 \mathrm{~h}$, the NACtreated cells began to show protein at these later time points (figs $5 \mathrm{~b}$ and $5 \mathrm{~d}$ ). A similar pattern of protein expression was seen for ser15-p53 and p53 throughout the time-course (data not shown).

Summary of DNA damage and responses in A549 cells to particles in relation to relevant physicochemical properties and constituents are shown in table 3.

\section{DISCUSSION}

The genetic instability driving tumourigenesis is fuelled by DNA damage and by errors made by the DNA machinery [28]. DNA damage has been well documented following exposure to IR [29-32] and chemotherapy [33-35]. It is widely accepted that such exposures elicit DNA damage response, including ATM/ATR-dependent phosphorylation of proteins and molecules taking part in damage sensing, regulating cell cycle and maintaining DNA integrity $[30,35,36]$. Recent studies show that PM10 causes DNA damage through oxidative stress [37, 38 ] and CDNP are most likely to be the harmful components [5]. Oxidative stress, arising from the surfaces of the inhaled particles and reactions involving their associated metals and organic constituents, elicits pulmonary inflammation that is considered to drive local as well as systemic (e.g. cardiovascular) effects $[39,40]$. Moreover, NPs may be more potent at causing oxidative stress-driven DNA damage due to their 
a)

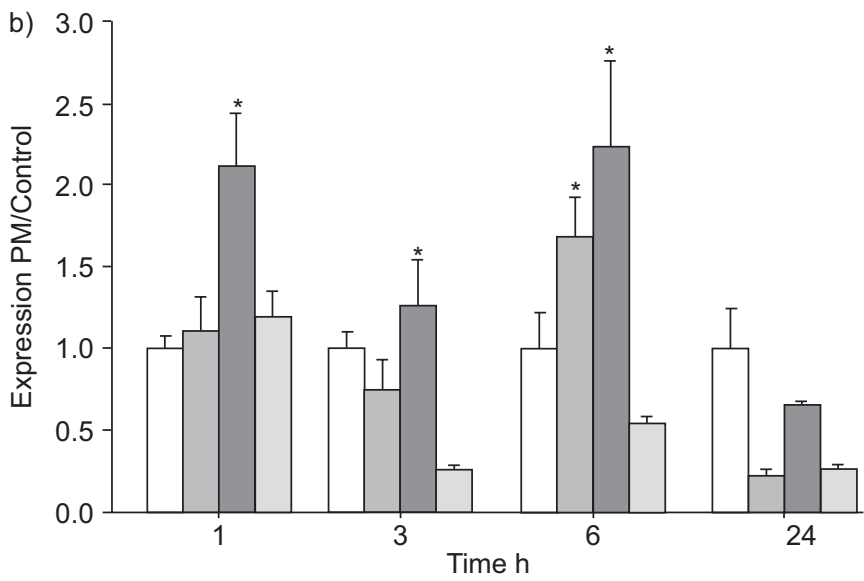

c)

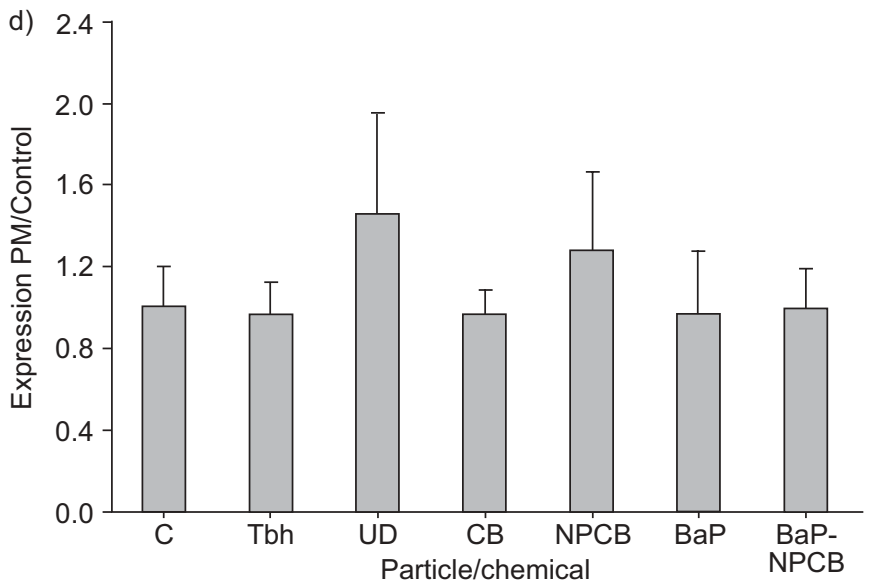

FIGURE 4. Tert-butyl-hyperperoxide (Tbh; $\square)$ induces histone H2A.X phosphorylation. $\mathrm{N}$-acetylcysteine effect on $\mathrm{p}-\mathrm{H} 2 \mathrm{~A}$.X expression. a, b) A549 cells were exposed to $75 \mu \mathrm{M}$ Tbh and $100 \mu \mathrm{g} \cdot \mathrm{mL}^{-1}$ of carbon black (CB; $\square$ ) and nanoparticulate carbon black (NPCB) and benzo(a)pyrene (BaP-NPCB; ${ }^{-1}$ ). c, d) A549 cells were exposed to $50 \mu \mathrm{M}$ tbh and particulate matter for $24 \mathrm{~h} . \mathrm{a}, \mathrm{c}$ ) representative Western blot gels. b, d) Values are shown as mean \pm SEM. C: control; UD: urban dust. *: $p<0.05$ compared with control; **: $p<0.01$ compared with control.

greater surface area. Despite such evidence, there are no existing data on how cells sense, and/or react to PM10 and/or NP-induced DNA damage. The present authors hypothesised that PM10, specifically its NP component, would have signalling pathways similar to IR. If this is the case, long-term exposure to particles may be a consequence of similar errors in DNA replication, resulting in carcinogenesis, and hence may provide an explanation for increased cancer incidence in polluted areas [1].

In the present study, all the NP test agents caused DNA damage after $3 \mathrm{~h}$ exposure. The most profound damage, DSBs, were observed only with UD. DSBs caused by UD treatment occurred after only $1 \mathrm{~h}$ and were found to persist, probably due to the continuous presence of the particles in the cell culture. The decline in DSBs observed at $24 \mathrm{~h}$ might reflect either repair or loss of cells that have undergone apoptosis following severe DNA damage. Metal-dependent oxidative stress might be a major mechanism for the strand breakage caused by UD, which, in contrast to the other dusts, is relatively rich in various metals [41]. DSBs induced by metal exposure have been investigated previously. HA et al. [17] found that $\mathrm{Cr}(\mathrm{VI})$ exposure of normal human fibroblasts lead to DSBs formation in the S-phase but not in $G_{1}$ synchronised cells, indicating S-phase-dependency. XIE et al. [36] suggest that, in human bronchial cells, lead chromate clastogenesis is mediated by the extracellular dissolution of the particles and not their internalisation. These findings have important implications for the understanding of the physicochemical mechanism of particulate chromates.

In the present study, SSBs were observed with NP, Tbh and $\mathrm{BaP}$, but not with coarse $\mathrm{CB}$. The ability of $\mathrm{Tbh}$ or $\mathrm{BaP}$ to induce DSBs is a topic of ongoing debate. The present data are consistent with findings of DNA breaks in Balb-c cells exposed to PM10 by AlFARO-MORENO et al. [42] and BusCHINI et al. [43], who found that NP fraction of airborne particulate generally caused the most DNA damage in human lung fibroblasts. In the present study, exposure of A549 cells to UD resulted in transient arrest of cell cycle passage. After 6-24 hours of exposure, UD caused $\mathrm{G}_{0} / \mathrm{G}_{1}$ cell arrest; Tbh exposure led to $\mathrm{G}_{0} / \mathrm{G}_{1}$ cell arrest and S-phase accumulation; while NPCB and $\mathrm{BaP}$ caused transient $\mathrm{G}_{2} / \mathrm{M}$ block.

Although DNA damage by ambient air particles has been investigated by several researchers [36], data on the molecular responses to this damage are rather scarce in comparison with investigations using IR. JOHNSON et al. [44] demonstrated that exposure of A549 cells to asbestos fibres induced a dosedependent increase in the G2 phase cell numbers. Aneuploidy was associated with an increase in the protein levels of genes such as p53, Cip1 and Gadd45, which are induced by DNA damage. OKAYASU et al. [45] showed early DSBs formation by asbestos. They found that $24-\mathrm{h}$ exposure of $\mathrm{xrs}-5$ cells to asbestos fibres resulted in lower cell survival accompanied by a cell growth delay, as well as a higher DNA DSBs induction in this mutant cell line [45]. Neonatal rats exposed to NP soot and iron particles show a significantly reduced cell proliferation rate in the proximal alveolar region, suggesting that exposure to airborne particles during early neonatal life may have significant direct effects on lung growth by altering cell division [46]. The combustion by-product, $\mathrm{BaP}$, is a prevalent airborne environmental mutagen and constituent of cigarette smoke. In a study reported by BINKOVÁ et al. [47], the cell cycle of diploid lung fibroblasts was altered after $12-24 \mathrm{~h}$ of exposure to $0.1 \mu \mathrm{M}$ dibenzo(a,1)pyrene, resulting in an $\sim 24 \%$ increase in S-phase. Enhanced benzo(a)pyrene-diol-epoxide (BPDE)-DNA adducts in response to BPDE resulted in $\mathrm{G}_{2} / \mathrm{M}$ retardation or apoptosis [48]. Consistent with the present results, subsequent elevation in the proportion of $G_{2} / M$ was reported by ZHU and GOODERHAM [49]. Increased DNA ploidy induced resistance to confluence-initiated cell death and the morphological change was accompanied by substantial changes in growth pattern, indicating that selection of carcinogen-induced transformants, under prolonged confluence culture, may be the pivotal mechanism of neoplastic disease development. 
a)
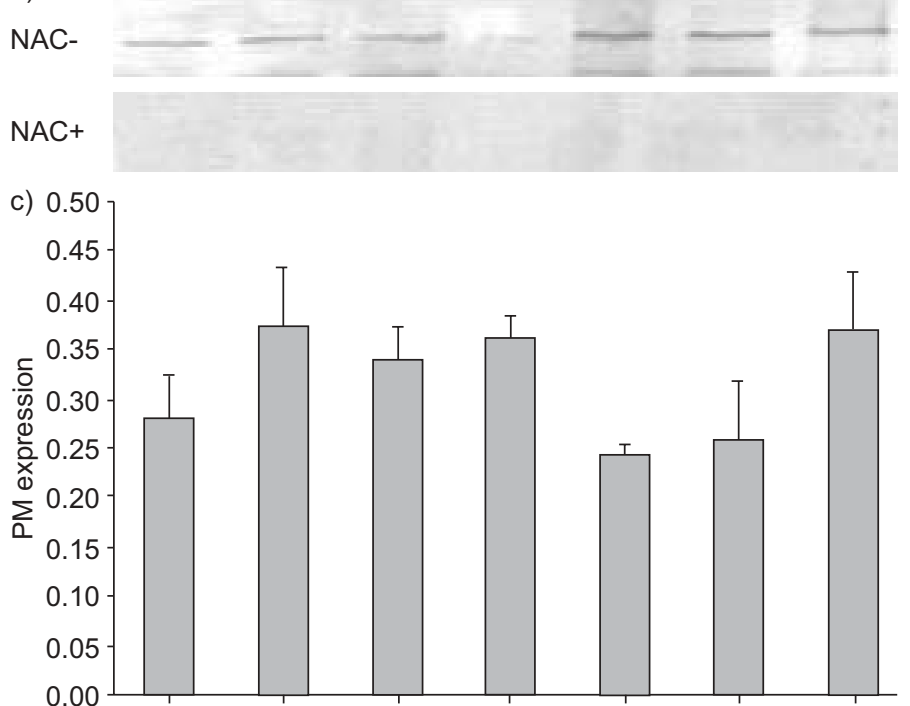

e)

NAC-

NAC+

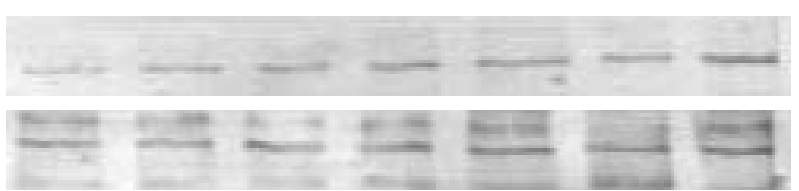

g) 0.8

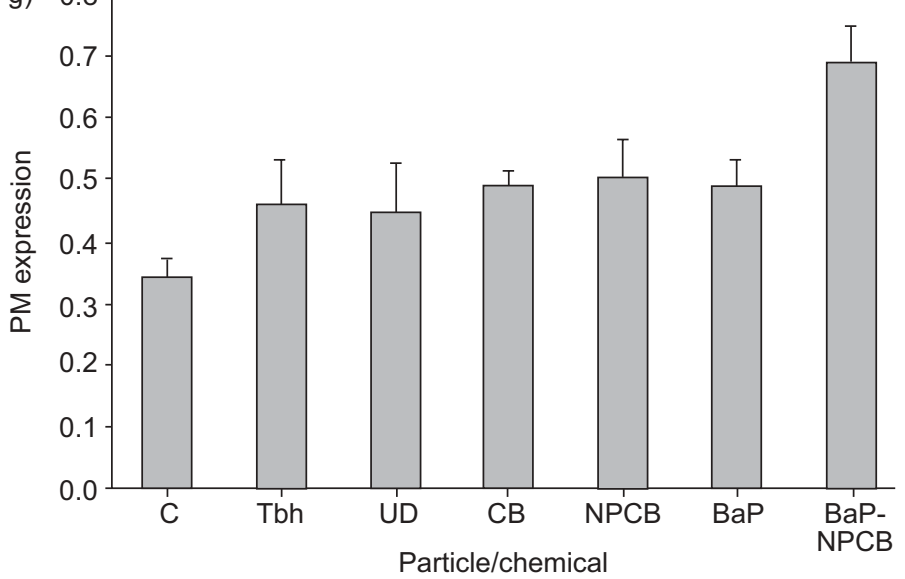

b) NAC-

NAC+

d)

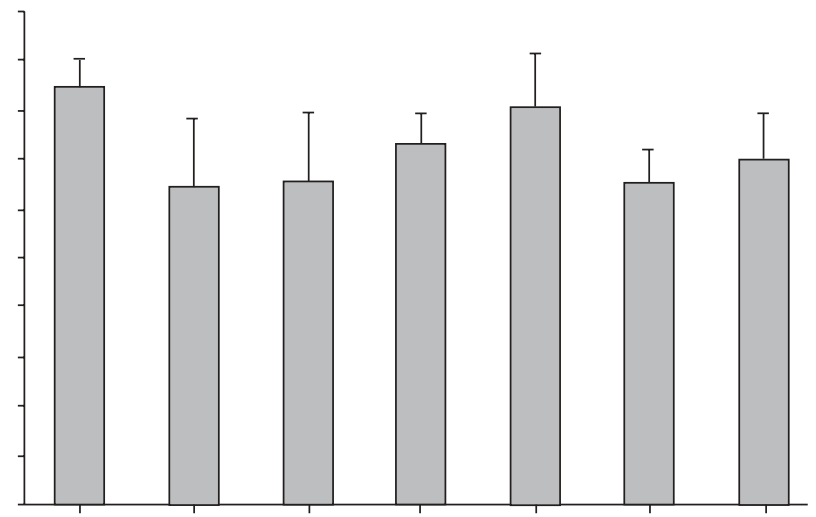

f)

NAC-

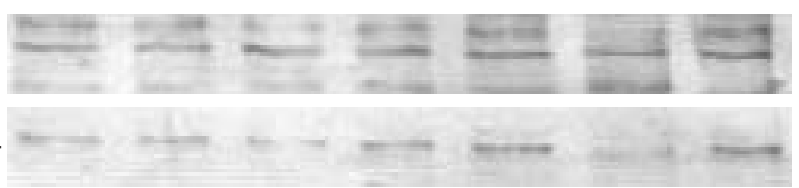

h)

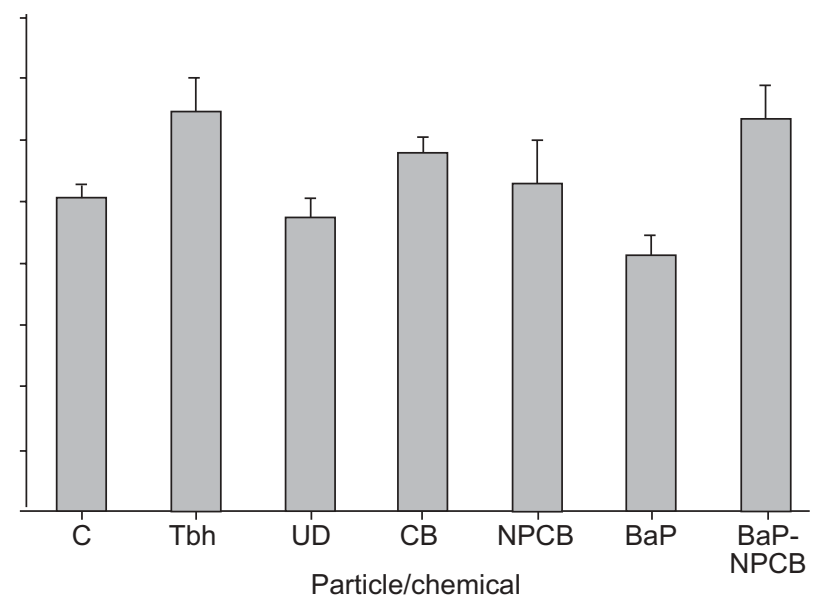

FIGURE 5. BRCA1 phosphorylation. N-acetylcysteine blocks BRCA1 phosphorylation up to $3 \mathrm{~h}$. a, b, e, f) representative Western blot gels and c, d, g, h) phosphorBRCA1 mean expression. A549 cells were exposed to particulate matter in $2 \mathrm{mM} \mathrm{N}$-acetylcysteine $0 \%$ Medium. Data are displayed as mean \pm SEM. C: control; Tbh: tert-butylhyperperoxide; UD: urban dust; CB: carbon black; NPCB: nanopartivulate carbon black; BaP: benzo(a)pyrene; BaP-NPCB: nanoparticulate carbon black and benzo(a)pyrene. *: $p<0.05$ compared with control under $N$-acetylcysteine conditions; ${ }^{* *}$ : $p<0.01$ compared with control under $N$-acetylcysteine conditions.

In the current study, p53 phosphorylation was observed at ser15, which occurred at early time-points in response to nearly all the tested NPs, peaking at $1 \mathrm{~h}$. NAC blocked p53 activation at early time points, suggesting the involvement of oxidative stress. Other investigators [50, 51] have shown involvement of p53 in the differential regulation of p21 mitogen-activated protein kinase and retinoblastoma in cellular response to oxidative stress and oxidative stress-induced apoptosis. Although the "genome guardian" role of p53 has mainly been studied with reference to apoptosis, recent findings [52] suggest that p53 is also activated in the early stages of DNA damage promoting signalling events, which leads to repair of damaged cells. HAMMOND et al. [53] reported that p53 ser15 and histone H2A.X were both phosphorylated in response to hypoxia in an ATR-dependent manner, and in response to reoxygenation-induced DNA damage in an ATMdependent manner. Again, in these studies phosphorylation was inhibited by NAC, indicating a ROS-driven pathway. In the present study, phosphorylation of BRCA1, subsequently blocked by NAC pre-treatment, phosphorylation of H2A.X and expression of 53BP1 was observed within early time points (figs 3-5). Previously, the functional interaction between histone H2A.X, ATR-interacting protein, as well as the BRCTmotif-containing molecules 53BP1, MDC1, and BRCA1 were exclusively studied in IR and/or chemotherapy models [22]. 53BP1 was phosphorylated in response to DNA damage and 


\begin{tabular}{|c|c|c|c|c|c|c|c|c|}
\hline TABLE 3 & \multicolumn{8}{|c|}{$\begin{array}{l}\text { Summary of DNA damage and responses in A549 cells to particles in relation to relevant physicochemical properties } \\
\text { and constituents }\end{array}$} \\
\hline \multicolumn{2}{|l|}{ Particle } & SSB & DSB & Cell cycle & $\begin{array}{l}\mathrm{p}-\mathrm{ser} 15-\mathrm{p} 53 \text { at } \\
1-2 \mathrm{~h}\end{array}$ & $\mathrm{p}-\mathrm{H} 2 \mathrm{~A} . \mathrm{X}$ at $1-6 \mathrm{~h}$ & p-BRCA1 at $6 \mathrm{~h}$ & $53 \mathrm{BP} 1$ at $1 \mathrm{~h}$ \\
\hline \multicolumn{2}{|c|}{ Carbon black } & - & - & - & - & - & - & - \\
\hline \multicolumn{2}{|c|}{ Tert-butyl-hyperperoxide } & ++ & - & $\mathrm{G}_{0} / \mathrm{G}_{1}$ & +++ & + & + & + \\
\hline \multicolumn{2}{|c|}{ Nanoparticulate carbon black } & +++ & - & $\mathrm{G}_{2} / \mathrm{M}$ & ++ & + & + & + \\
\hline \multicolumn{2}{|c|}{$\begin{array}{l}\text { Nanoparticulate carbon black }+ \\
\text { benzopyrene }\end{array}$} & +r+ & - & - & + & + & + & + \\
\hline \multicolumn{2}{|c|}{ Benzopyrene } & +++ & - & $\mathrm{G}_{2} / \mathrm{M}$ & + & + & + & ++ \\
\hline
\end{tabular}

SSB: single-strand breaks; DSB: double-strand breaks; p-ser15-p53: p53 phosphorylated at ser15; p-H2A.X: phospho-histone H2A.X; p-BRCA1: phospho-BRCA1 53BP1: p53 binding protein 1. -: no effect; +: small response; ++: moderate response; +++: large response.

rapidly relocalised to presumptive sites of DNA damage along with the phosphorylated histone 2A variant, $\gamma$-H2A.X. FERNANDEZ-CAPETILLO et al. [54] reported that mice lacking either H2A.X or 53BP1, but not Chk2, manifest a $\mathrm{G}_{2} / \mathrm{M}$ checkpoint defect close to that observed in ATM(-/-) cells after exposure to low, but not high, doses of IR. Moreover, H2A.X

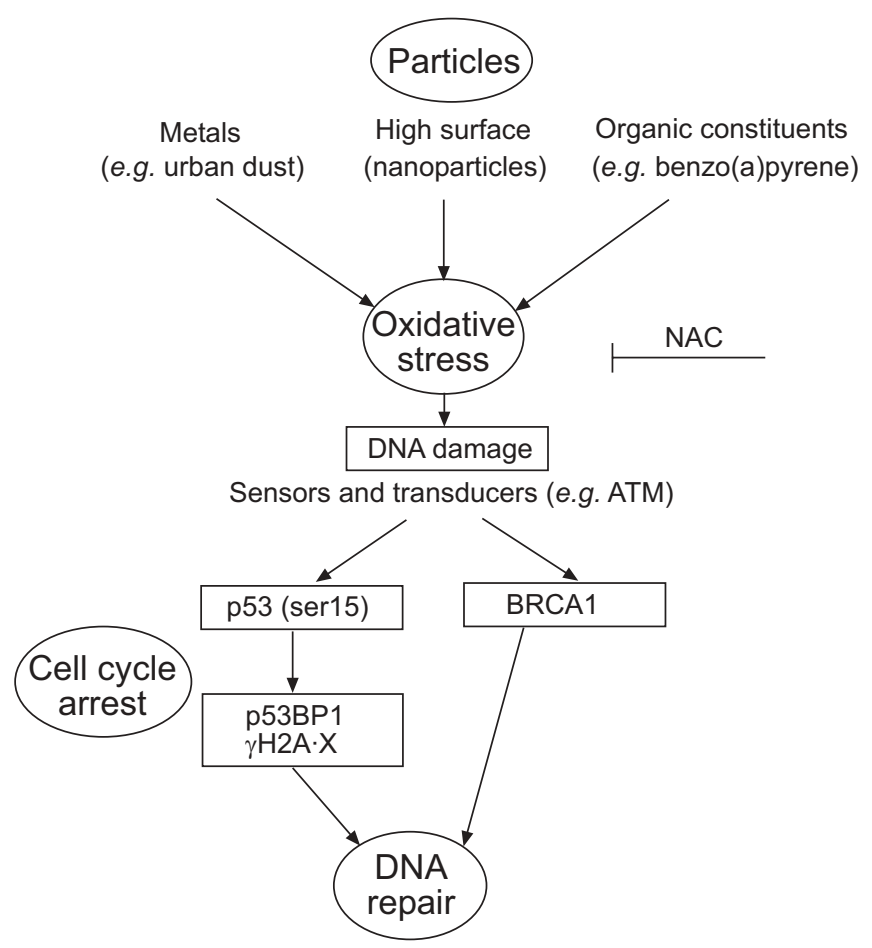

FIGURE 6. Postulated signalling pathway induction associated with DNA damage by (nano)particles and their constituents. Air pollution particles have been implicated in the ability to elicit oxidative stress and associated DNA damage, as also previously indicated with the use of antioxidants such as $\mathrm{N}$-acetylcysteine (NAC). In the present study, (transition) metals, aromatic compounds, and most importantly, the reactive surface or nanoparticles have been implicated. Selected markers of particle-mediated DNA damage responses as determined in this study are shown in the boxes. ATM: ataxia/teleangiectasia mutated kinase. regulated the ability of 53BP1 to efficiently accumulate into IR-induced foci. MORALES et al. [55] found that 53BP1 deficient mice were sensitive to $\gamma$-IR, and cells from these animals exhibit chromosomal abnormalities consistent with defects in DNA repair. These animals were growth-retarded and showed various immune deficiencies, including a specific reduction in thymus size and T-cell count. The increased chromosomal instability and tumour susceptibility apparent in mutant mice deficient in both p53 and either histone H2A.X or proteins that contribute to the nonhomologous end-joining mechanism of DNA repair, indicate that DNA damage check-points play a pivotal role in tumour suppression. AlBINO et al. [56] proposed a H2A.X phosphorylation-based test to be applied for testing potential carcinogens in products. Further studies are needed to assess the direct or indirect link between oxidative stressdriven DNA damage, ATM/ATR dependent signalling pathway and transcription factors. Since different particles may have different effects, further investigation is also needed into the effect of NP exposure and oxidative stress on ATMdependent and independent gene expression changes, as well as on focus formation by DNA checkpoint signalling and repair factors to NP.

In conclusion, in the present study the expression of DNA damage-inducible genes, which previously have been shown to be involved in responses to IR treatment, was determined. Since the IR-induced DNA damage response is highly complexed, selected parameters were focused on in order to identify possible similarities in DNA damage response signals by particles. This is schematically shown in figure 6 .

Indeed, the present data provide some first clues for the potential of air pollution particles, specifically their nanoparticulate components, to act on similar signalling pathways in pulmonary epithelial cells. Current findings justify further investigation on the elucidation of the role(s) that particles play in disruption of mechanisms that regulate cell-cycle checkpoints, DNA repair and apoptosis, and which are known to culminate in genomic instability. Such information, improved by exploration of particulate matter interactions should shed light on the well-documented relationship between exposure to ambient particulate matter and cancer. 


\section{REFERENCES}

1 Pope CA 3rd, Burnett RT, Thun MJ, et al. Lung cancer, cardiopulmonary mortality, and long-term exposure to fine particulate air pollution. JAMA 2002; 287: 1132-1141.

2 Health effects of outdoor air pollution. Committee of the Environmental and Occupational Health Assembly of the American Thoracic Society. Am J Respir Crit Care Med 1996; 153: 3-50.

3 Shi T, Knaapen AM, Begerow J, Birmili W, Borm PJ, Schins RP. Temporal variation of hydroxyl radical generation and 8-hydroxy-2'-deoxyguanosine formation by coarse and fine particulate matter. Occup Environ Med 2003; 60: 315-321.

4 Harrison RM, Jones M. The chemical-composition of airborne particles in the UK atmosphere. Sci Total Environ 1995; 168: 195-214.

5 Donaldson K, Tran L, Jimenez LA, et al. Combustionderived nanoparticles: a review of their toxicology following inhalation exposure. Part Fibre Toxicol 2005; 2: 10.

6 Warheit DB, Webb TR, Colvin VL, Reed KL, Sayes CM. Pulmonary bioassay studies with nanoscale and finequartz particles in rats: toxicity is not dependent upon particle size but on surface characteristics. Toxicol Sci 2007; 95: 270-280.

7 Xia T, Kovochich M, Brant J, et al. Comparison of the abilities of ambient and manufactured nanoparticles to induce cellular toxicity according to an oxidative stress paradigm. Nano Lett 2006; 6: 1794-1807.

8 Donaldson $\mathrm{K}$, Stone V, Borm PJ, et al. Oxidative stress and calcium signaling in the adverse effects of environmental particles (PM10). Free Radic Biol Med 2003; 34: 1369-1382.

9 Donaldson K, Brown D, Clouter A, et al. The pulmonary toxicology of ultrafine particles. J Aerosol Med 2002; 15: 213-220.

10 Donaldson K, Stone V, Clouter A, Renwick L, MacNee W. Ultrafine particles. Occup Environ Med 2001; 58: 211-216.

11 Donaldson K, Stone V, Gilmour PS, Brown DM, MacNee W. Ultrafine particles: mechanisms of lung injury. Philos Trans $R$ Soc Lond A 2000; 358: 2741-2749.

12 Donaldson K, Stone V. Current hypotheses on the mechanisms of toxicity of ultrafine particles. Ann Ist Super Sanita 2003; 39: 405-410.

13 Kawanishi S, Hiraku Y, Murata M, Oikawa S. The role of metals in site-specific DNA damage with reference to carcinogenesis. Free Radic Biol Med 2002; 32: 822-832.

14 Bryszewska M, Piasecka A, Zavodnik LB, Distel L, Schüssler $H$. Oxidative damage of Chinese hamster fibroblasts induced by t-butyl hydroperoxide and by Xrays. Biochim Biophys Acta 2003; 1621: 285-291.

15 Finnberg N, Silins I, Stenius U, Högberg J. Characterizing the role of MDM2 in diethylnitrosamine induced acute liver damage and development of pre-neoplastic lesions. Carcinogenesis 2004; 25: 113-122.

16 Rusyn I, Asakura S, Pachkowski B, et al. Expression of base excision DNA repair genes is a sensitive biomarker for in vivo detection of chemical-induced chronic oxidative stress: identification of the molecular source of radicals responsible for DNA damage by peroxisome proliferators. Cancer Res 2004; 64: 1050-1057.

17 Ha L, Ceryak S, Patierno SR. Generation of S phasedependent DNA double-strand breaks by $\mathrm{Cr}(\mathrm{VI})$ exposure: involvement of ATM in $\mathrm{Cr}(\mathrm{VI})$ induction of $\gamma-\mathrm{H} 2 \mathrm{AX}$. Carcinogenesis 2004; 25: 2265-2274.

18 O'Brien TJ, Ceryak S, Patierno SR. Complexities of chromium carcinogenesis: role of cellular response, repair and recovery mechanisms. Mutat Res 2003; 533: 3-36.

19 Kim H, Liu X, Kobayashi T, et al. Ultrafine carbon black particles inhibit human lung fibroblast-mediated collagen gel contraction. Am J Respir Cell Mol Biol 2003; 28: 111-121.

20 Wang QE, Han CH, Yang YP, et al. Biological effects of man-made mineral fibers (II)-their genetic damages examined by in vitro assay. Ind Health 1999; 37: 342-347.

21 Giaccia AJ, Kastan MB. The complexity of p53 modulation: emerging patterns from divergent signals. Genes Dev 1998; 12: 2973-2983.

22 Kastan MB, Bartek J. Cell-cycle checkpoints and cancer. Nature 2004; 432: 316-323.

23 Prahalad AK, Inmon J, Dailey LA, Madden MC, Ghio AJ, Gallagher JE. Air pollution particles mediated oxidative DNA base damage in a cell free system and in human airway epithelial cells in relation to particulate metal content and bioreactivity. Chem Res Toxicol 2001; 14: 879-887.

24 Dasenbrock C, Peters L, Creutzenberg O, Heinrich U. The carcinogenic potency of carbon particles with and without $\mathrm{PAH}$ after repeated intratracheal administration in the rat. Toxicol Lett 1996; 88: 15-21.

25 Borm PJ, Cakmak G, Jermann E, et al. Formation of PAHDNA adducts after in vivo and vitro exposure of rats and lung cells to different commercial carbon blacks. Toxicol Appl Pharmacol 2005; 205: 157-167.

26 Lips J, Kaina B. DNA double-strand breaks trigger apoptosis in p53-deficient fibroblasts. Carcinogenesis 2001; 22: 579-585.

27 Schins RP, Knaapen AM, Cakmak GD, Shi T, Weishaupt C, Borm PJ. Oxidant-induced DNA damage by quartz in alveolar epithelial cells. Mutat Res 2002; 517: 77-86.

28 Hoeijmakers JH. Genome maintenance mechanisms for preventing cancer. Nature 2001; 411: 366-374.

29 Viniegra JG, Martínez N, Modirassari P, et al. Full activation of $\mathrm{PKB} / \mathrm{Akt}$ in response to insulin or ionizing radiation is mediated through ATM. J Biol Chem 2005; 280: 4029-4036.

30 Ismail IH, Nyström S, Nygren J, Hammarsten O. Activation of ataxia telangiectasia mutated by DNA strand break-inducing agents correlates closely with the number of DNA double strand breaks. J Biol Chem 2005; 280: 4649-4655.

31 Matsuoka S, Nakagawa T, Masuda A, Haruki N, Elledge SJ, Takahashi T. Reduced expression and impaired kinase activity of a Chk2 mutant identified in human lung cancer. Cancer Res 2001; 61: 5362-5365.

32 Chen MJ, Lin YT, Lieberman HB, Chen G, Lee EY. ATMdependent phosphorylation of human Rad9 is required for ionizing radiation-induced checkpoint activation. J Biol Chem 2001; 276: 16580-16586.

33 Omori S, Takiguchi Y, Suda A, et al. Suppression of a DNA double-strand break repair gene, Ku70, increases radioand chemosensitivity in a human lung carcinoma cell line. DNA Repair (Amst) 2002; 1: 299-310.

34 Miknyoczki SJ, Jones-Bolin S, Pritchard S, et al. Chemopotentiation of temozolomide, irinotecan, and 
cisplatin activity by CEP-6800, a poly(ADP-ribose) polymerase inhibitor. Mol Cancer Ther 2003; 2: 371-382.

35 Kemp CJ, Sun S, Gurley KE. p53 induction and apoptosis in response to radio- and chemotherapy in vivo is tumortype-dependent. Cancer Res 2001; 61: 327-332.

36 Xie H, Wise SS, Holmes AL, et al. Carcinogenic lead chromate induces DNA double-strand breaks in human lung cells. Mutat Res 2005; 586: 160-172.

37 Knaapen AM, Borm PJ, Albrecht C, Schins RP. Inhaled particles and lung cancer. Part A: Mechanisms. Int J Cancer 2004; 109: 799-809.

38 Knaapen AM, Shi T, Borm PJ, Schins RP. Soluble metals as well as the insoluble particle fraction are involved in cellular DNA damage induced by particulate matter. Mol Cell Biochem 2002; 234-235: 317-326.

39 Donaldson K, Jimenez LA, Rahman I, et al. Respiratory health effects of ambient air pollution particles: role of reactive species. In: Vallyathan $\mathrm{V}$, Shi $\mathrm{X}$, Castranova V, eds. Oxygen/Nitrogen Radicals: Lung Injury and Disease. New York, Marcel Dekker, 2004.

40 Donaldson $\mathrm{K}$. The biological effects of coarse and fine particulate matter. Occup Environ Med 2003; 60: 313-314.

41 Möller W, Hofer T, Ziesenis A, Karg E, Heyder J. Ultrafine particles cause cytoskeletal dysfunctions in macrophages. Toxicol Appl Pharmacol 2002; 182: 197-207.

42 Alfaro-Moreno E, Martínez L, García-Cuellar C, et al. Biologic effects induced in vitro by PM10 from three different zones of Mexico City. Environ Health Perspect 2002; 110: 715-720.

43 Buschini A, Cassoni F, Anceschi E, Pasini L, Poli P, Rossi C. Urban airborne particulate: genotoxicity evaluation of different size fractions by mutagenesis tests on microorganisms and comet assay. Chemosphere 2001; 44: 1723-1736.

44 Johnson NF, Jaramillo RJ. p53, Cip1, and Gadd153 expression following treatment of A549 cells with natural and man-made vitreous fibers. Environ Health Perspect 1997; 105: Suppl. 5, 1143-1145.

45 Okayasu R, Takahashi S, Yamada S, Hei TK, Ullrich RL. Asbestos and DNA double strand breaks. Cancer Res 1999; 59: 298-300.

46 Pinkerton KE, Zhou YM, Teague SV, et al. Reduced lung cell proliferation following short-term exposure to ultrafine soot and iron particles in neonatal rats: key to impaired lung growth? Inhal Toxicol 2004; 16: Suppl. 1, 73-81.

47 Binková B, Giguère Y, Rössner P Jr, Dostál M, Srám RJ. The effect of dibenzo[a,1]pyrene and benzo[a]pyrene on human diploid lung fibroblasts: the induction of DNA adducts, expression of p53 and p21(WAF1) proteins and cell cycle distribution. Mutat Res 2000; 471: 57-70.

48 Shinozaki R, Inoue S, Choi KS. Flow cytometric measurement of benzo[a]pyrene-diol-epoxide-DNA adducts in normal human peripheral lymphocytes and cultured human lung cancer cells. Cytometry 1998; 31: 300-306.

49 Zhu H, Gooderham N. Neoplastic transformation of human lung fibroblast MRC-5 SV2 cells induced by benzo[a]pyrene and confluence culture. Cancer Res 2002; 62: 4605-4609.

50 Chung YW, Jeong DW, Won JY, Choi EJ, Choi YH, Kim IY. $\mathrm{H}_{2} \mathrm{O}_{2}$-induced AP-1 activation and its effect on p21(WAF1/CIP1)-mediated G2/M arrest in a p53-deficient human lung cancer cell. Biochem Biophys Res Commun 2002; 293: 1248-1253.

51 Marwick JA, Kirkham P, Gilmour PS, Donaldson K, MacNee W, Rahman I. Cigarette smoke-induced oxidative stress and TGF- $\beta_{1}$ increase p21waf1/cip1 expression in alveolar epithelial cells. Ann N Y Acad Sci 2002; 973: 278-283.

52 Das KC, Dashnamoorthy R. Hyperoxia activates the ATRChk1 pathway and phosphorylates p53 at multiple sites. Am J Physiol Lung Cell Mol Physiol 2004; 286: L87-L97.

53 Hammond EM, Dorie MJ, Giaccia AJ. ATR/ATM targets are phosphorylated by ATR in response to hypoxia and ATM in response to reoxygenation. J Biol Chem 2003; 278: 12207-12213.

54 Fernandez-Capetillo O, Chen HT, Celeste A, et al. DNA damage-induced G2-M checkpoint activation by histone H2AX and 53BP1. Nat Cell Biol 2002; 4: 993-997.

55 Morales JC, Xia Z, Lu T, et al. Role for the BRCA1 Cterminal repeats (BRCT) protein 53BP1 in maintaining genomic stability. J Biol Chem 2003; 278: 14971-14977.

56 Albino AP, Huang X, Jorgensen E, et al. Induction of H2AX phosphorylation in pulmonary cells by tobacco smoke: a new assay for carcinogens. Cell Cycle 2004; 3: 1062-1068. 